\title{
PENTINGNYA PENGETAHUAN ANATOMI \\ UNTUK 3D ARTIST
}

\author{
Anton Sugito Kurniawan
}

\begin{abstract}
No matter how far the current technological advances, anatomical knowledge will still be needed as a basis for making a good character design. Understanding anatomy will help us in the placement of the articulation of muscles and joints, thus more realistic modeling of $3 d$ characters will be achieved in the form and movement. As a 3d character artist, anatomy should be able to inform in every aspect of our work. Each 3D/CG (Computer Graphics)-artist needs to know how to use software applications, but what differentiates a 3d artist with a computer operator is an artistic vision and understanding of the basic shape of the human body. Artistic vision could not easily be taught, but a CG-artist may study it on their own from which so many reference sources may help understand and deepen their knowledge of anatomy.
\end{abstract}

Keywords: anatomy, human body, 3D computer graphics

\begin{abstract}
ABSTRAK
Seberapapun jauh kemajuan teknologi sekarang ini, pengetahuan anatomi masih akan diperlukan sebagai dasar membuat disain karakter yang baik. Dengan memahami anatomi akan membantu kita dalam penempatan artikulasi otot serta persendian, sehingga modelling $3 d$ karakter akan menjadi realistik dalam bentuk dan pergerakannya. Sebagai artis karakter3d, anatomi harus bisa menginformasikan setiap aspek dari hasil pekerjaan kita. Setiap 3d/CG (Computer Graphics) -artist perlu mengetahui bagaimana menggunakan software aplikasi, tetapi apa yang membedakan seorang 3d artist dengan seorang operator komputer saja adalah visi artistik dan pemahaman dasar bentuk tubuh manusia. Visi artistik tidak dapat dengan mudah diajarkan, tetapi seorang cg-artist bisa dengan serius mempelajari sendiri dari sumber referensi yang begitu banyak membantu memahami dan memperdalam pengetahuan anatomi.
\end{abstract}

Kata kunci: anatomi, tubuh manusia, grafik komputer 3D 


\section{PENDAHULUAN}

Pengetahuan anatomi dalam pertemuan di kelas tidak akan cukup untuk menjelaskan seluruh aspek penting tentang fungsi dan susunan otot yang membentuk struktur tubuh yang disebut anatomi. Kemampuan seorang 3d-artist membuat modelling 3d karakter akan terlihat seiring dengan pemahamannya tentang anatomi. Dalam tulisan ini dipaparkan betapa pentingnya pengetahuan anatomi tubuh dengan penguasaan dasar anatomi disini akan memberikan gambaran akan pentingnya memperdalam pengetahuan tentang otot, tulang dan persendian serta proporsi tubuh. Tentu saja berdasar pada pengalaman penulis dan referensi dari buku-buku anatomi serta tips \& trik dari para $3 d$ experts. Untuk pengetahuan lebih lanjut tentang anatomi tubuh dapat diperdalam melalui buku-buku anatomi, karena dengan pemahaman yang kuat tentang anatomi maka pekerjaan karakter disain kita akan semakin kuat dan kuat lagi.

\section{METODE}

Penulisan materi diperoleh dari rangkuman banyak pengalaman dari 3d-artist yang sudah berpengalaman yang membagi tips \& triknya dalam berbagai forum diskusi dalam dan luar negeri. Study anatomi disini lebih ditekankan kepada materi anatomi untuk mendukung kemampuan modelling 3d karakter, jadi tidak terlalu dalam membahas detail, hanya anatomi otot, rangka dan persendian (Gambar 1). Buku anatomi dari Gottfried Bammes, Andrew Loomis dan banyak gambar literatur dari internet dipakai dalam tulisan ini.
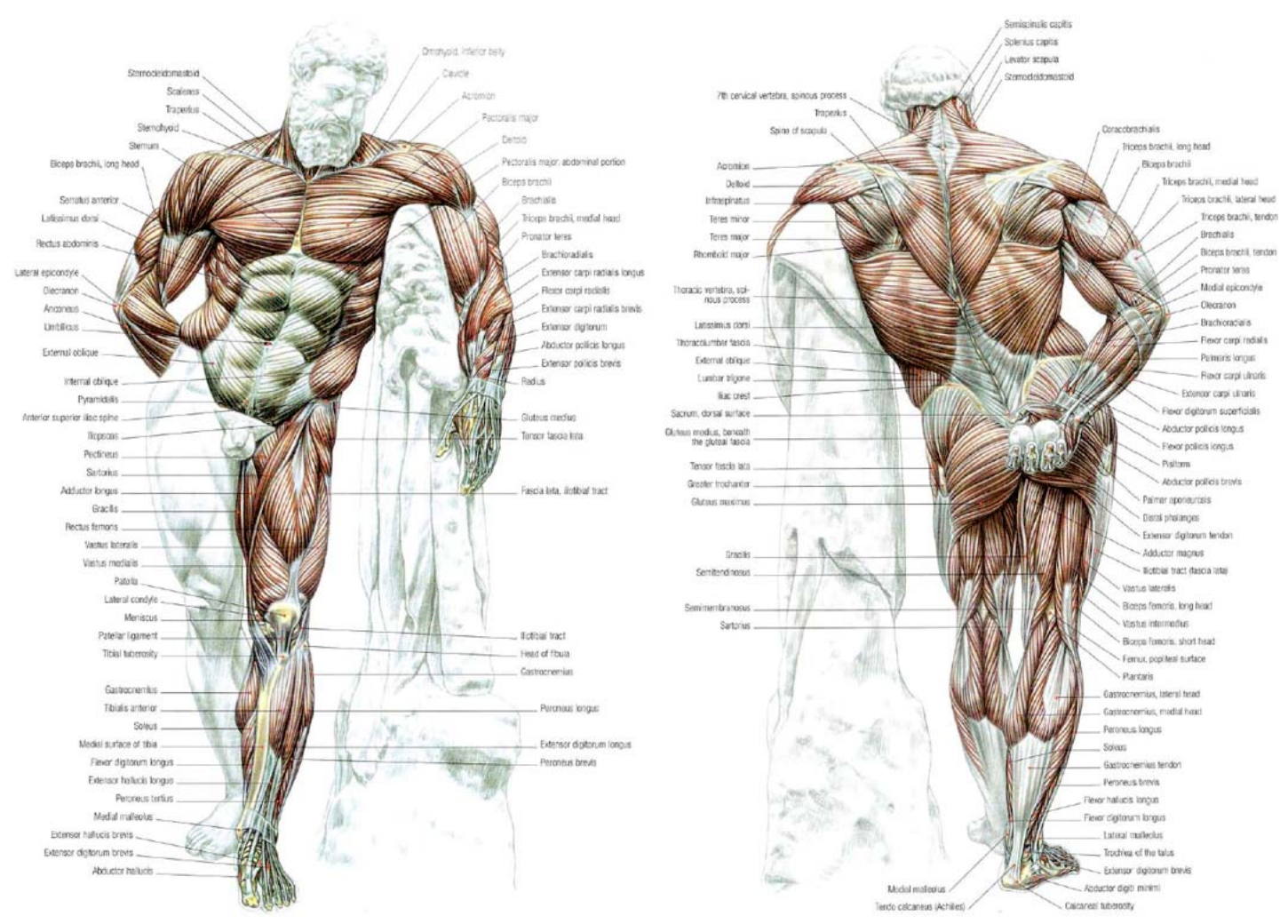

Gambar 1 Anatomi Tubuh Manusia secara Utuh 


\section{HASIL DAN PEMBAHASAN}

\section{Pendekatan seperti Seorang Pematung}

Pendekatan ini mengupayakan untuk mendahulukan bentuk globalnya terlebih dahulu sebelum melakukan detailing. Di komputer grafis, terutama dalam software 3d terbaru yang memungkinkan kita memahat detail secara cepat dan mudah, disana langsung bisa membuat detail tekstur kerut keriput serta urat pada permukaan kulit dari karakter, bahkan bisa dibuat sebelum bentuk globalnya dibentuk secara utuh. Namun sebaiknya pendekatan seperti seorang pemahat kuno saat bekerja pada media batu menjadi acuan kita karena sangat membantu dalam memahami struktur dari proses konstruksinya. Bayangkan tentang bagaimana seorang pematung harus memahat batu diawali dengan membuat bloking dengan sangat hati-hati membentuk proporsi bentuk globalnya dahulu. Setelah bentuk global didapat barulah pengerjaan detailnya dipahat.

\section{Memeriksa Siluet}

Memeriksa siluet model kita adalah cara yang terbaik untuk menilai secara garis besar proporsi dan gesture. Langkah ini memudahkan tanpa terganggu oleh detail yang belum jadi dan yang akan dibentuk kemudian. Hanya perlu men-set model tanpa warna shading yang akan mempermudah kita konsentrasi hanya ke bentuk utama dan mengabaikan model yang belum benar-benar selesai di detail.

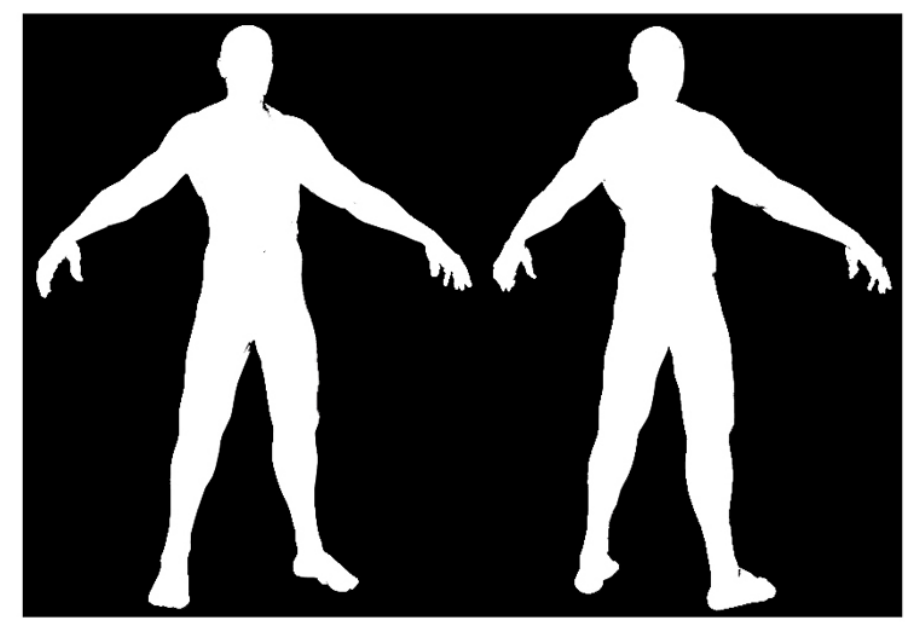

Gambar 2 Contoh Gambar Siluet

\section{Mempelajari Tengkorak dan Kerangka Tubuh}

Kerangka adalah dasar bentuk dari karakter apapun baik manusia, hewan atau yang lain dan harus dipahami sebelum mengerti otot agar karakter kita masuk akal. Pada saat klien meminta kita untuk model jas tergantung di lemari. Untuk menjadi 3d-artist yang mengikuti permintaan klien, kita harus menanyakan dua pertanyaan untuk membuat yakin klien mendapatkan apa yang sedang ia butuhkan: paling jelas, jenis jas apa yang dimaksud itu? Namun, mungkin lebih penting, kita akan juga bertanya, bagaimana bentuk gantungan itu? Sama seperti gantungan yang menentukan bentuk dari jaket menggantung, kerangka menentukan bentuk otot-otot tubuh dan tergantung. Selain penguat yang menetapkan proporsi tubuh, kerangka berfungsi sebagai titik awal dan titik akhir untuk semua otot yang menempel pada rangka. 


\section{Konsepsi Massa untuk Penyederhanaan Rangka}

Sangat penting untuk memiliki mental penyederhanaan bentuk besar dari kerangka. Dengan konsepsi massa sederhana dari rangka tubuh, tulang rusuk dan panggul, sebuah figure bisa digambarkan dengan sketsa cepat untuk menunjukkan keseimbangan dan proporsi. Masing-masing massa kalau digambarkan secara detail akan begitu rumit, tapi dengan penyederhanaan bentuknya yang rumit itu menjadi figure yang simple dan bisa dipahami setiap artist/ seniman. Baik Gottfried Bammes maupun Andrew Loomis telah melakukan itu dengan bentuk figure sederhana atau kita kenal sebagai stick figure (Gambar 3).

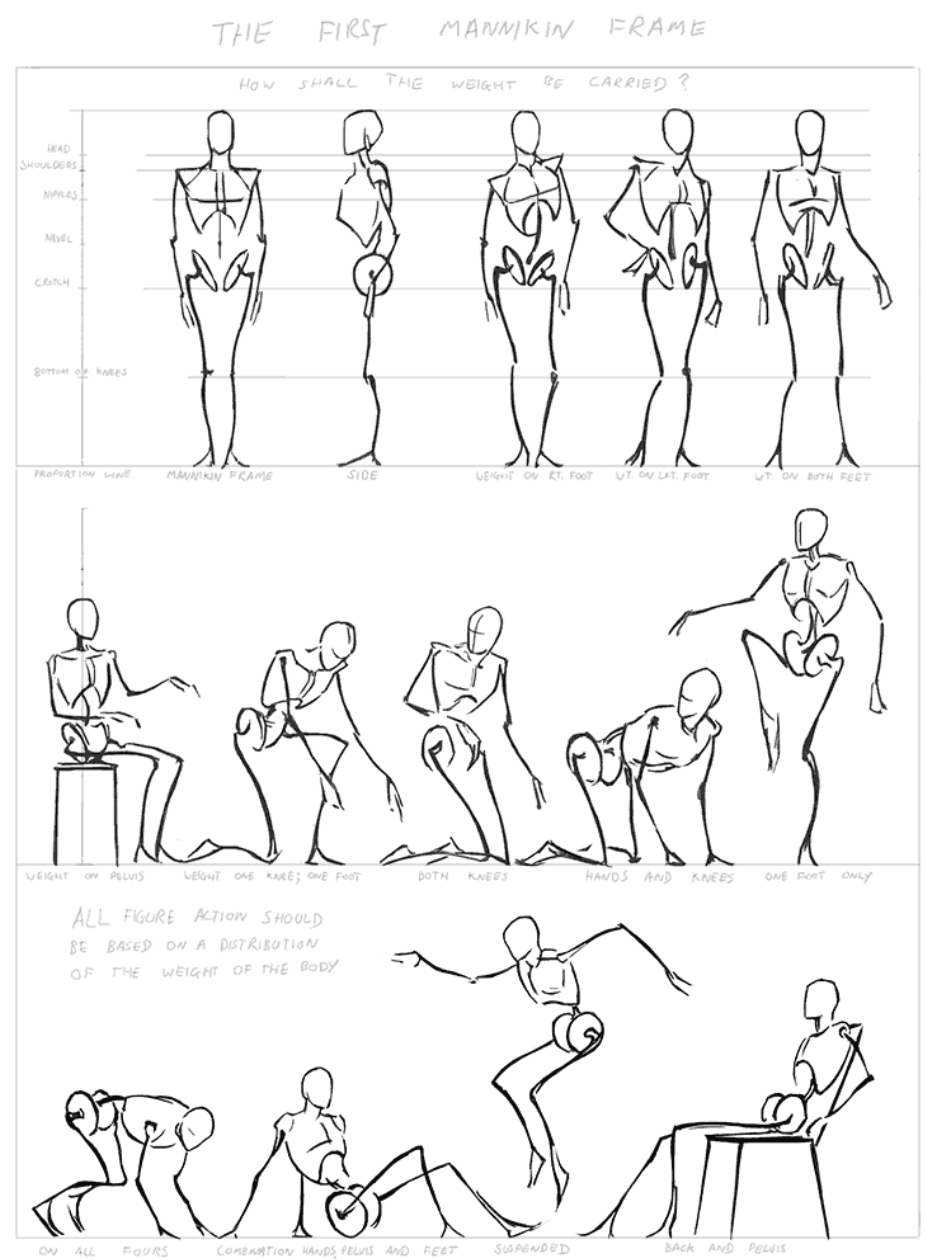

Gambar 3 Gambar dengan menggunakan Stick Figure

\section{Menggambar Struktur dalam Model Kita}

Harus selalu ada garis struktur yang mendasari konstruksi model kita. Hal ini dicapai dengan mempertahankan konsepsi massa sebelum mulai menempatkan ke otot-otot tubuh. Sebuah teknik sederhana di CG adalah benar-benar menciptakan konsepsi penyederhanaan garis konstruksi di bawah kulit model kita. Ini akan berfungsi sebagai referensi untuk pemodelan bentuk otot di bagian atas, dan juga referensi selama rigging untuk memastikan deformasi tidak melanggar apa yang dimaksudkan untuk menjadi kerangka kaku di bawahnya. 


\section{Titik Tulang Rangka (Bony Points)}

Kita telah mengetahui pentingnya kerangka dan memahami penyederhanaan massa rangka tubuh dari panggul dan tulang rusuk, tetapi apa selanjutnya? Nah, kita perlu mempelajari titik tulang yang menonjol pada permukaan tubuh (bony points). Ini adalah tempat di mana tulang rangka terletak langsung di bawah kulit (Gambar 4). Tonjolan tulang ini menjadi penanda untuk menetapkan proporsi tubuh dan menempatkan kumpulan otot secara akurat. Tidak hanya itu, ini adalah tempat pada model kita saat kita melakukan rigging, tidak boleh terdeformasi sama sekali dan harus bergerak kaku bersama dengan sendi.

Beberapa titik point ini adalah titik bahu (acromion process), tulang belakang skapula, vertebra servikalis ketujuh, titik tulang pinggul (anterior dan posterior superior Iliac spines), dan titik siku (Olecranon dan epicondyles humerus).

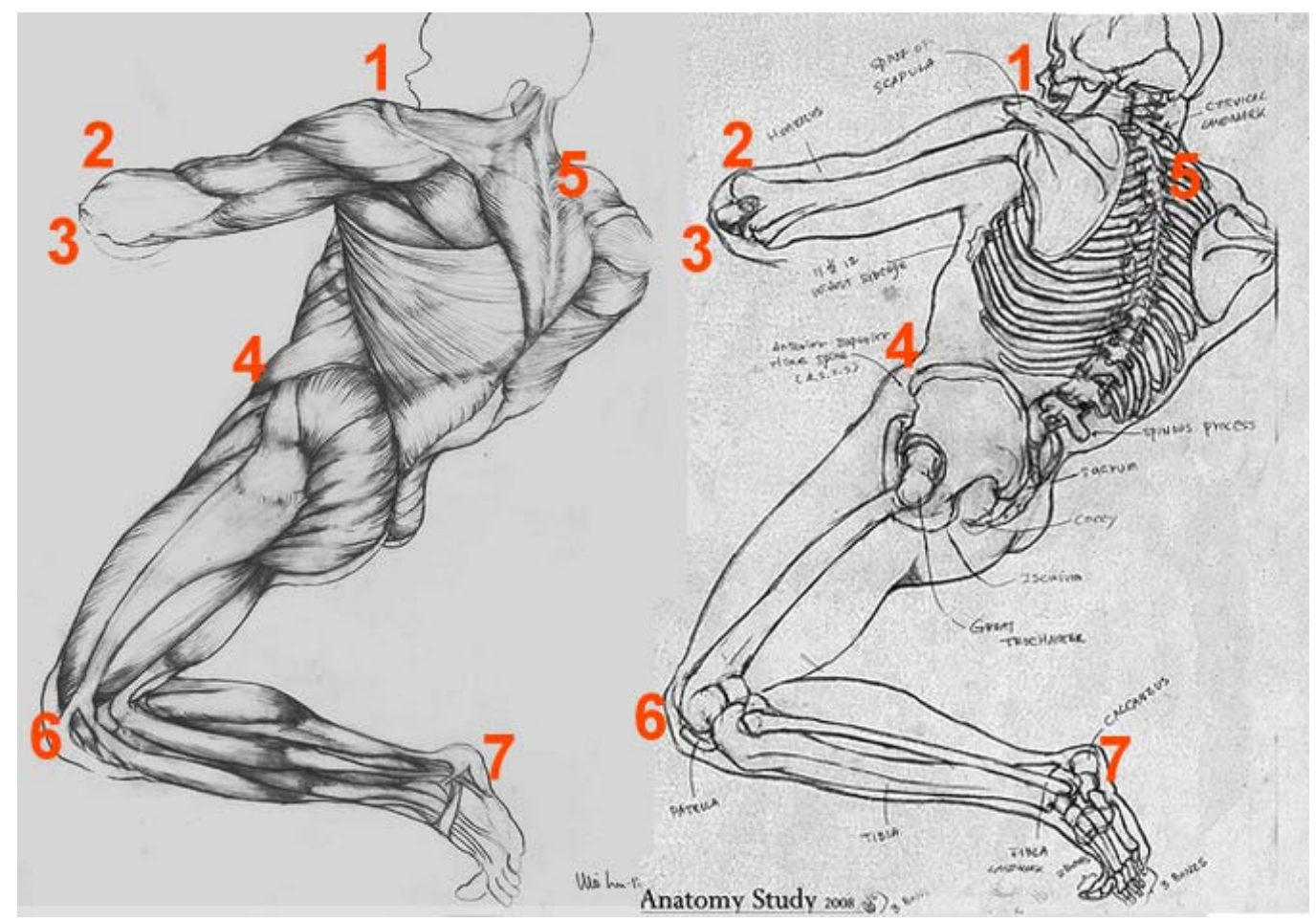

Gambar 4 Posisi Titik-Titik Tulang Rangka

Titik tonjolan tulang menentukan bagaimana dan di mana ujung otot bermula dan menempel pada tulang. Memahami letak otot menempel dimana akan membantu kita untuk menentukan arah tarik otot, disaat figur berpose apapun. Ketentuan ini menjadi acuan bagaimana edge flow pada modelling harus ditata.

\section{Kekuatan Gaya Tarik}

Salah satu aspek struktural yang paling penting untuk memahami tentang otot adalah bahwa otot-otot selalu setidaknya mempunyai satu gabungan fungsi. Sebuah prinsip mekanik sederhana memberikan otot kekuatan gaya tarik. Otot yang menempel pada satu tulang akan menggabungkan dengan tulang lain yang berurutan pada hirarkinya. Konsep sederhana yang saling mempengaruhi antar penggabungan otot keduanya secara dinamis dan meyakinkan. 
Pada siku contohnya, ada saling mempengaruhi antara otot pangkal dan lengan bawah (Gambar 5). Otot lengan bawah memanjang sampai diatas siku, menempel pada tulang lengan atas (humerus). Demikian juga otot bisep dan trisep memanjang sampai bawah siku menempel pada tulang lengan bawah. Prinsip saling pengaruh mempengaruhi tersebut terjadi diseluruh otot tubuh yang lain juga, sehingga membuat model body dengan pertimbangan otot-otot bisa terlihat lebih kuat.

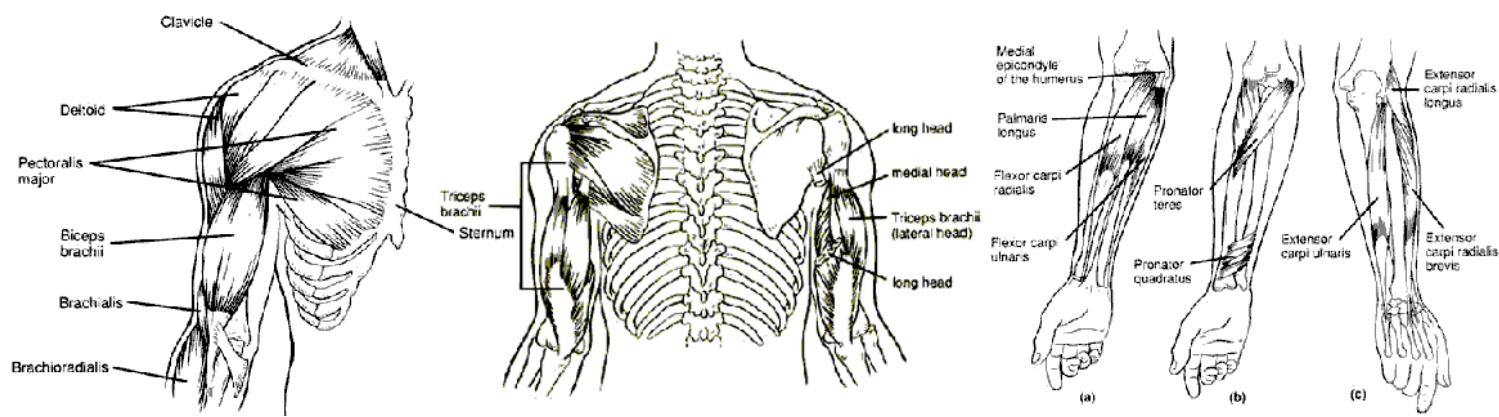

Gambar 5 Anatomi Otot Lengan

\section{Lengan Bawah}

Dua area otot yang paling rumit dari tubuh adalah lengan bawah dan skapula. Keduanya memiliki kompleksitas dengan jumlah otot dan arah otot yang saling tarik menarik. Pemahaman mengenai dua area ini akan memerlukan studi tambahan, jadi kita abaikan dulu masalah ini. Saat kita perhatian lebih detail ke otot lengan, ujung dari menempelnya otot bisep dan otot trisep terlihat begitu simpel, namun otot-otot lengan bawah jauh lebih kompleks. Sebagai acuan untuk membantu belajar dimulai dengan memahami struktur tulang lengan atas dan tulang lengan bawah (humerus). Ada dua benjolan penting disana (epicondyles): satu dibagian luar dan satunya didalam. Kedua benjolan masing-masing, yang ekstensor dan fleksor berasal dari telapak tangan. Fleksor merentang di bagian dalam lengan bawah, sedangkan ekstensor merentang di bagian luar atas.

\section{Skapula}

Banyak kerumitan dibagian tulang belakang - sering para pemula salah memperkirakan penempatan tonjolan, ini karena skapula (tulang belikat) semua ototnya melekat dan bergeser di atas tulang rusuk. Untuk mengatasi kerumitan area ini, mulailah dengan memahami bentuk tulang skapula. Bentuk tulang seperti peta panduan untuk menempatkan otot. Tulang belakang skapula merupakan tulang penanda penting yang akan memberikan orientasi tulang dan disposisi otot-otot yang berada di sana.

\section{Kulit dan Lemak}

Setelah mengenal secara detail dari studi otot, adalah sangat penting memperhatikan penampilan otot seperti apa tanpa lapisan teratas yakni lemak dan kulit. Lapisan ini berbentuk lunak dan kadang dalam beberapa tempat menutup detail otot dibawahnya. Pengaruh lapisan kulit dan lemak pada otot seperti melihat melalui kaca buram, kita masih bisa melihat bentuk dan massa di balik kaca, tapi detailnya kabur dan hilang. Selalu melakukan cross check referensi otot dengan foto atau gambar yang memperlihatkan bentuk yang sebenarnya dari obyek yang nyata. 


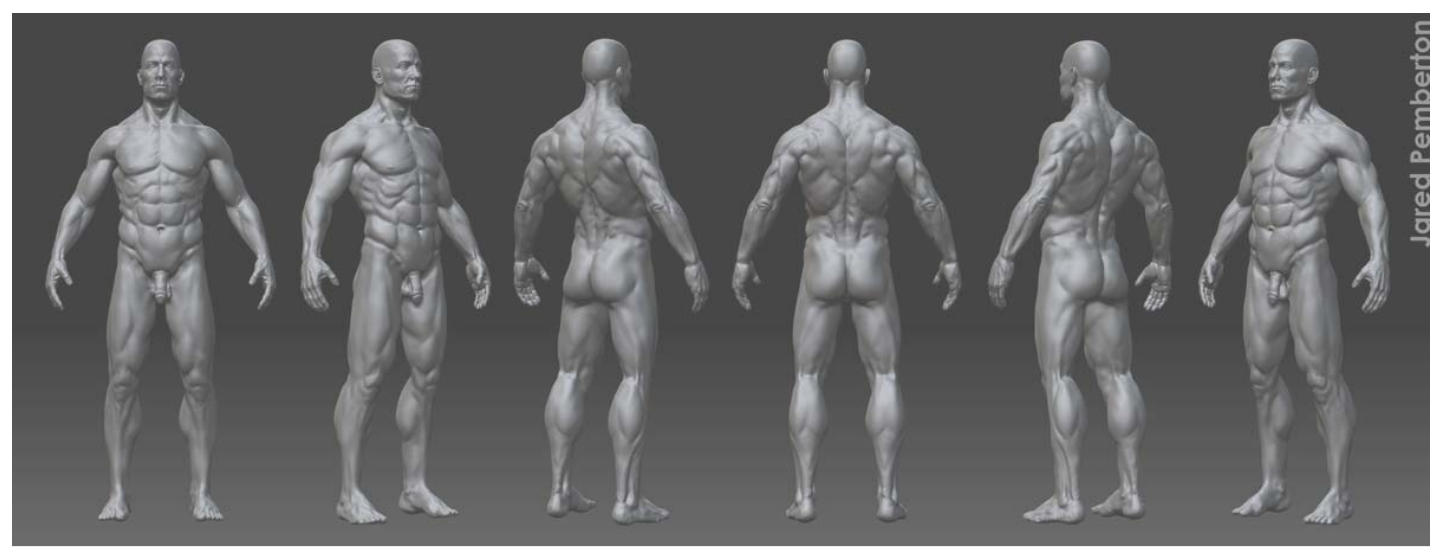

Gambar 6 Anatomi Luar

\section{Menggambar Langsung (Life Drawing)}

Tidak ada yang bisa menggantikan untuk belajar anatomi melalui figur nyata, jadi lakukan sketsa gambar secara langsung (life drawing). Kelas menggambar kadang terlalu terburu-buru untuk menyelesaikan gambar secara akurat. Disini ada teknik yang direkomendasi:

Dalam menggambar suatu pose, fokuslah gambar pada bagian tertentu dari tubuh dan perbanyak waktu untuk mempelajari struktur tulang dan bentuk otot di daerah itu. Lakukan studi pada area sempit sampai selesai. Dengan metode ini, kita akan memiliki lebih banyak waktu untuk mengamati bentuk dan rincian dari otot-otot di daerah tersebut, daripada menggambar keseluruhan figure. Ini lebih baik dilakukan karena akan mempercepat pelajaran anatomi kita.

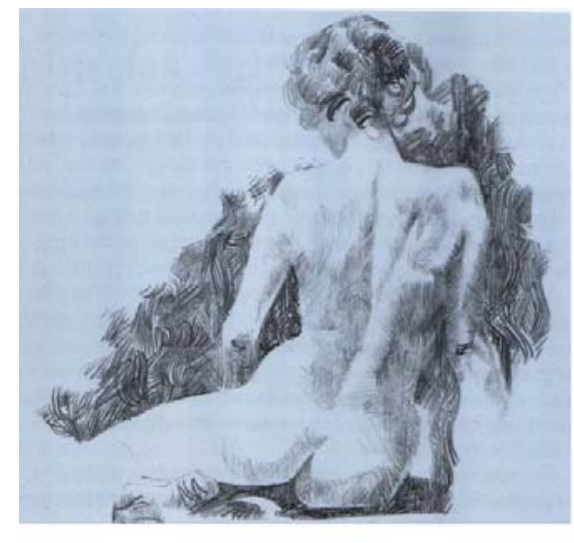

Life Drawing Study
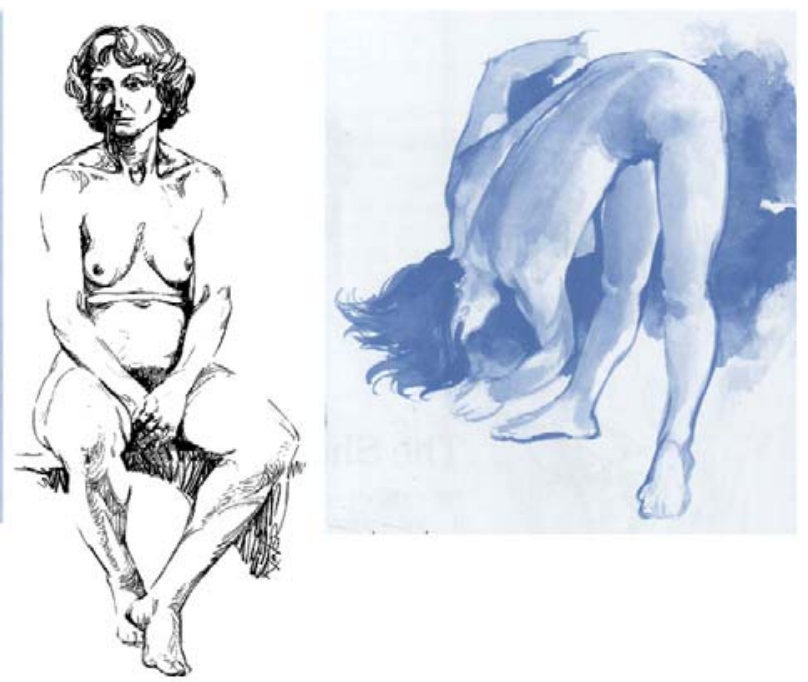

Gambar 7 Hasil Latihan Menggambar Pose Langsung

\section{Anatomi Hewan}

Setelah kita memahami anatomi manusia, maka akan cukup mudah belajar anatomi hewan. Kita mungkin terkejut bahwa binatang memiliki anatomi yang sangat mirip dengan manusia, perbedaan hanya variasi dalam proporsi. Mereka memiliki scapulae, fleksor, ekstensor dan semua hal 
yang telah kita bicarakan, hanya dalam ukuran dan bentuk yang berbeda. Sayap dari kelelawar misalnya, memiliki hirarki tulang persis sama dengan lengan manusia dan tangan, sampai ke jumlah terkecil dari jari - hanya proporsi dan fungsi berbeda. Belajar anatomi manusia dengan baik dan kita segera akan dapat memahami anatomi hewan.

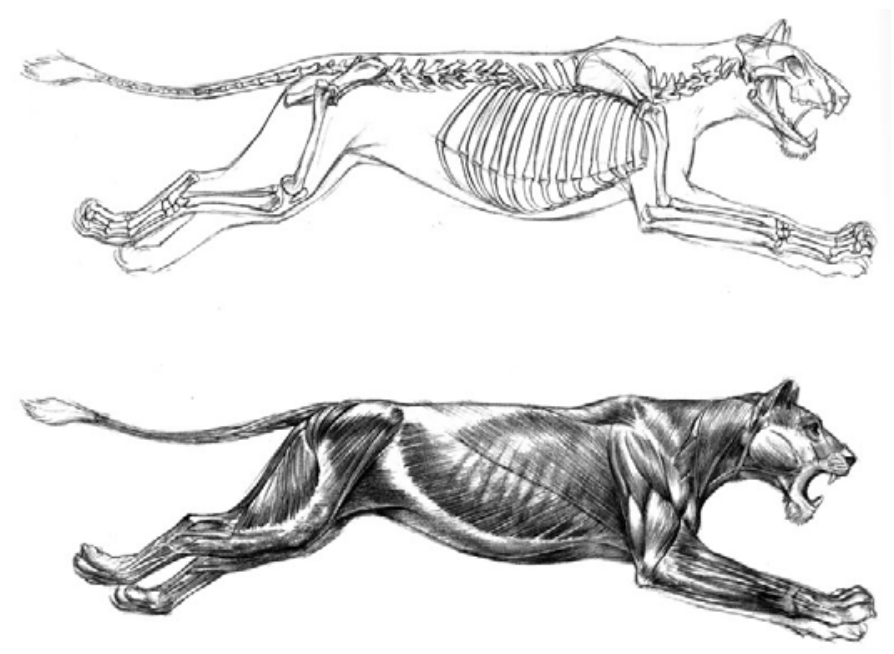

Gambar 8 Anatomi Hewan

\section{Anatomi yang Masuk Akal}

Prinsip yang diuraikan di atas dapat dan harus diterapkan pada makhluk fantasi juga. Mengingat bahwa makhluk fantasi berada di dunia dengan fisika mirip dengan kita sendiri, dengan demikian akan mempunyai mekanisme yang sama berlaku terhadap gravitasi, massa dan momentum. Gunakan pengetahuan kita tentang anatomi manusia untuk membayangkan bagaimana makhluk monster mungkin akan dibangun dengan otot dan tulang sehingga dapat bereaksi terhadap lingkungan sekitarnya (Gambar 9).

Mempertimbangkan semua poin disebutkan di sini. Membuat catatan dari kerangka yang mendasarinya, titik tonjolan tulang, asal otot dan letak melekatnya. Pertimbangkan saling hubungan antar otot dan tendon di seluruh sendi. Pinjam dari anatomi manusia tetapi perubahan proporsi dan fungsi yang diperlukan.

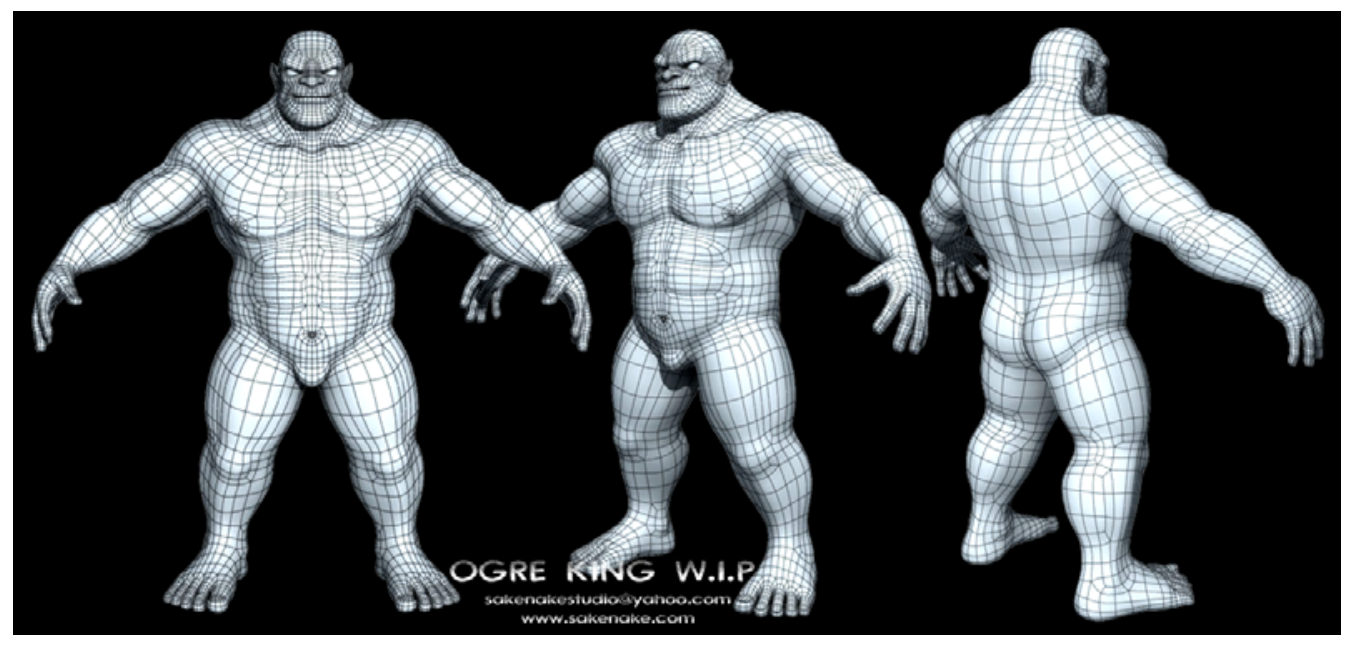

Gambar 9 Anatomi yang masuk akal untuk hal yang tidak masuk akal 


\section{PENUTUP}

Setelah mengenal dan mempelajari anatomi, mesti diketahui juga kalo figure yang ada dalam buku yang sering dijadikan sebagai contoh adalah figure idealnya manusia. Dalam realitas beragamnya perbedaan suku ras dan variasi genetik manusia, menciptakan perbedaan yang jauh dari kesan ideal tersebut. Hal inilah yang membuat kita perlu melakukan observasi. Lakukan study variasi masing-masing individu ini, di ruang publik atau alat transportasi umum, adalah kesempatan kita mempelajari perbedaan struktur tubuh dan wajah. Semakin banyak melakukan latihan akan membuatmu semakin sempurna.

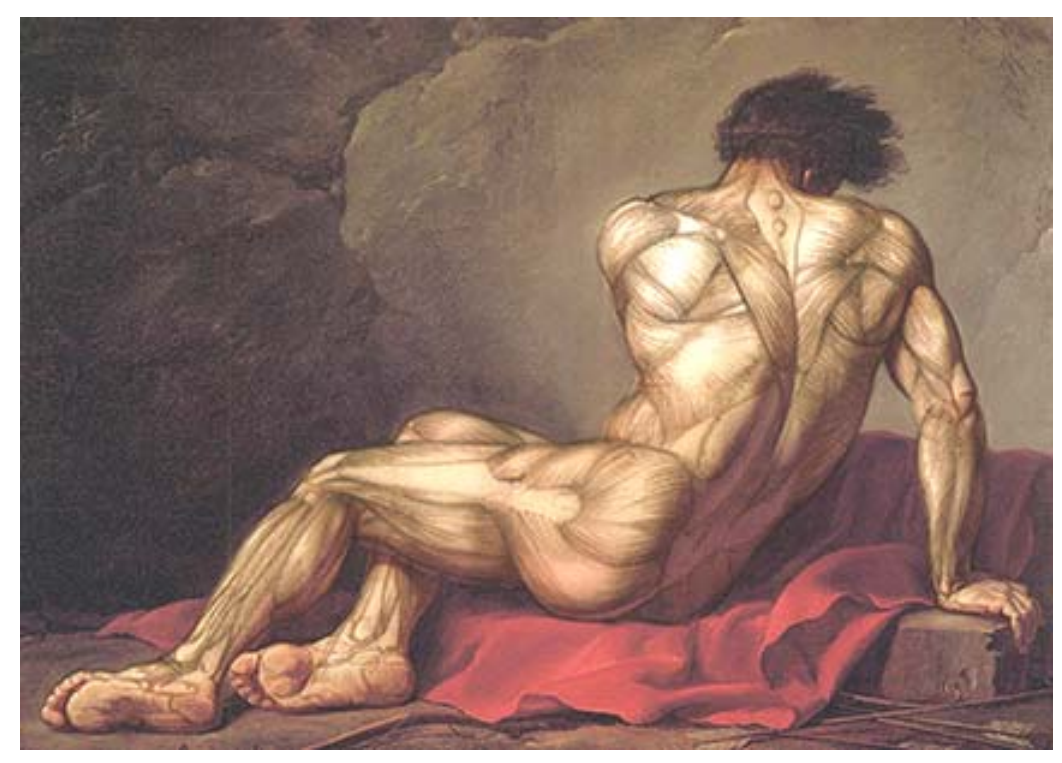

Gambar 10 Gambar dengan Teknik E'corche'

Cara belajar anatomi yang baik menggunakan teknik e'corche' yaitu menggambar figur tanpa kulit, sebuah teknik yang sederhana kembali ke abad 15. Dimulai dengan menggunakan gambar referensi yang memperlihatkan otot, di atasnya dengan lapisan transparan temukan dulu titik tulang yang menonjol (bony points) baru gambarkan otot di area sekitarnya dan pastikan arahnya benar.

\section{DAFTAR PUSTAKA}

Lommis, A. (1982). Figure Drawing for All Its Worth, New York: Viking Press.

Bammes, G. (2002). Die Gestalt des Menschen , Germany: Ravensburger B Otto Maier GmbH, 